\title{
LOW BACK PAIN \\ A SURVEY CONDUCTED AT THE ARMY MEDICAL REHABILITATION UNIT, CHESTER - 1969
}

\author{
Lieutenant-Colonel A. R. ROBINSON, \\ M.B., Ch.B., M.R.C.P.E., D.Phys.Med., D.T.M.\&H., R.A.M.C. \\ Military Hospital, Catterick *
}

\begin{abstract}
SUMMARY. Four hundred and forty-nine cases of low backache amongst Servicemen were surveyed and followed-up at between two and five years. There were 35.5 per cent considered to be fully fit, and $\mathbf{6 0 . 5}$ per cent left with some residual disability. Comparison was made with a similar survey amongst coalminers, and showed no significant difference in the proportions regaining fitness for normal work.
\end{abstract}

\section{Introduction}

The patient with low backache presents as a common problem in diagnosis, management and prognosis. It is clear that in many cases the underlying defect is poorly understood, and not unnaturally, treatment is all too frequently unrewarding. Whilst accepting that in some cases there is a variable, but appreciable functional overlay present, many of these patients are left with a degree of disability, which may affect their work potential. A large number of cases of chronic or recurrent low backache are seen in Servicemen, probably due in part to the active conditions relating to many aspects of Service life. The Serviceman with backache from whatever cause, presents as something of a problem in long term management, particuarly in relation to his job. The scale of the problem is probably not generally appreciated, and it was decided to conduct a retrospective survey amongst Servicemen who had been patients at the Army Medical Rehabilitation Unit, Chester with low backache, over a 4 year period. Particular emphasis was given to the long term outlook of these patients.

\section{Design}

Case notes of all patients who had been treated at the Unit with a history of low backache during the 4 year period 1964 to 1967 inclusive, were reviewed. Classification of the conditions presented something of a problem, but was resolved for the purposes of this survey by dividing all cases into one of three basic groups as follows:-

(a) Fractures of vertebral bodies. Twelfth dorsal to fifth lumbar inclusive, and either single or multiple.

(b) Lumbar intervertebral disc lesions. In these cases the diagnosis was based on the classical history and clinical findings as described by Armstrong (1965). A small proportion of these cases had had previous laminectomy performed, but symptoms persisted. It is likely that errors in diagnosis could have been made between this group and the next.

* Now: Royal Herbert Hospital, Woolwich, London SE18 4LJ. 
(c) Non-specific backache. As suggested in a Leading Article (British Medical Journal, October 1971), and comprising a heterogeneous group of conditions presenting as acute, chronic or recurrent low back pain, of a non-specific pattern, which on clinical grounds did not appear to be due to a lumbar disc lesion, and in which fracture had been excluded. This group included acute and chronic ligamentous strains, particularly of the supraspinous, interspinous, and ilio-lumbar ligaments, postural backache, and cases in whom a variety of bony abnormalities of the lumbosacral junction were noted on radiological examination, such as spondylolysis, spondylolisthesis, transitional fifth lumbar and first sacral vertebrae, with or without articulating transverse processes and spina bifida occulta. Also included in this group was one case of neurofibroma and one of arachnoid cyst, both of which were removed surgically. Cases of inflammatory spondylitis were specifically excluded from the survey. All cases were examined radiologically, and the majority had a full blood count, erythrocyte sedimentation rate estimation, and mid-stream specimen of urine examination. Treatment in all cases followed a general regime of graduated exercise therapy, hydrotherapy, postural exercises, and other routine treatments as indicated, such as lumbar traction, manipulation, local steroid and local anaesthetic infiltration. Follow-up, to ascertain the current medical category, was done by reference to the various Military records offices.

\section{Findings}

Over the 4 year period, a total of 449 patients were treated. The breakdown of these cases into the different groups is shown in Table I.

The acute cases were labelled so arbitrarily, and were those, usually of traumatic origin, where symptoms had settled within 4 weeks.

The age distribution is shown in Table II and shows no specific features of distribution apart from the non-specific group, where a statistically significant variation from the expected number of subjects is present. This would seem to be attributed to in the main by a significantly low observed number of subjects in the over 35 age group. The other groups show no statistically significant variation in the age distribution of the subjects.

The present situation of these patients is shown in Table III.

The overall figures show that only 35.5 per cent of patients were considered to be fully fit, whereas 60.5 per cent were left with some degree of residual disability. In 35.5 per cent this was of such a degree as to require invaliding from the Service. Further breakdown of the figures into the three condition groups is shown in Table IV.

The figures in the individual group breakdown show that in those with fracture, 39.5 per cent returned to full fitness, whereas 57 per cent were left with some degree of disability. In those with lumber disc lesions, the corresponding figures were only 19.5 per cent and 75 per cent, and in the non-specific group, 43.5 per cent and 53 per cent respectively. These are not very encouraging figures for fractures, and particularly lumbar disc lesions.

The outcome of the cases with radiological lumbosacral abnormalities, 18 per cent in all, is shown in Table $\mathrm{V}$, which shows that only 21 per cent of such cases return to full fitness, 72.5 per cent being left with some degree of residual disability. 
Table I

Classifications of conditions

\begin{tabular}{l|c|c}
\hline Diagnostic group & $\begin{array}{c}\text { Number of } \\
\text { subjects }\end{array}$ & \multicolumn{1}{|c}{ Remarks } \\
\hline $\begin{array}{l}\text { Fractures } \\
\text { Lumbar disc lesions } \\
\text { Non-specific backache }\end{array}$ & $\begin{array}{r}56 \\
250\end{array}$ & $\begin{array}{l}\text { Included 29 laminectomies, } \\
\text { Acute 57, chronic 191, cases with radiological lumboscacral } \\
\text { abnormalities 80, arachnoid cyst 1 and neurofibroma 1. }\end{array}$ \\
\hline
\end{tabular}

Table II

Distribution by age and condition group

\begin{tabular}{l|c|c|c|c|c}
\hline \multirow{2}{*}{ Diagnostic group } & \multicolumn{5}{|c}{ Age (years) } \\
\cline { 2 - 6 } & Under 20 & $20-25$ & $25-30$ & $30-35$ & Over 35 \\
\hline Fractures & 15 & 30 & 9 & - & 2 \\
Lumbar disc lesions & 21 & 56 & 32 & 20 & 14 \\
Non-specific backache & 71 & 106 & 40 & 14 & 19 \\
\hline \multicolumn{1}{c|}{ Totals } & 107 & 192 & 81 & 34 & 35 \\
\hline
\end{tabular}

Table III

Present disposal of subjects

\begin{tabular}{l|c|c|c|c|c}
\hline \multicolumn{1}{c|}{ Subjects } & Fully fit & $\begin{array}{c}\text { Döwngraded and } \\
\text { restricted duties }\end{array}$ & Invalided & $\begin{array}{c}\text { Not } \\
\text { traced }\end{array}$ & Totals \\
\hline Serving & 93 & 24 & $\overline{59} \ddagger$ & $\overline{19}$ & 117 \\
\hline Not serving & $66^{*}$ & $88 \dagger$ & 159 & 19 & 449 \\
\hline
\end{tabular}

Notes: * includes 2 deaths-one under anaesthetic (unrelated to backache condition), and one in a road accident. $\dagger$ Includes the patient with neurofibroma and two downgraded on psychiatric grounds. + Includes seven patients invalided on psychiatric grounds, one for thyrotoxicosis and the arachnoid cyst.

Table IV

Present disposal by groups

\begin{tabular}{|c|c|c|c|c|c|}
\hline Group & Fully fit & $\begin{array}{l}\text { Downgraded and } \\
\text { restricted duties }\end{array}$ & Invalided & $\underset{\text { traced }}{\text { Not }}$ & Totals \\
\hline $\begin{array}{l}\text { Fracture group } \\
\text { Serving } \\
\text { Not serving }\end{array}$ & $\begin{array}{r}17 \\
5\end{array}$ & $\begin{array}{l}1 \\
9\end{array}$ & $\overline{22}$ & $\overline{2}$ & $\begin{array}{l}18 \\
38\end{array}$ \\
\hline $\begin{array}{l}\text { Lumbar disc lesion group } \\
\text { Serving } \\
\text { Not serving } \\
\text { Note: Includes one patient }\end{array}$ & $\begin{array}{c}19 \\
9 \\
\text { invalided or }\end{array}$ & $\begin{array}{c}9 \\
32 \\
\text { ychiatric grounds }\end{array}$ & $\overline{66^{*}}$ & $\overrightarrow{8}$ & $\begin{array}{r}28 \\
115\end{array}$ \\
\hline $\begin{array}{l}\text { Non-specific group } \\
\text { Serving } \\
\text { Not serving }\end{array}$ & $\begin{array}{l}57 \\
52\end{array}$ & $\begin{array}{l}14 \\
47 \dagger\end{array}$ & $\overline{71^{*}}$ & $\overline{9}$ & $\begin{array}{r}71 \\
179\end{array}$ \\
\hline
\end{tabular}

Notes: * Includes six patients invalided on psychiatric grounds, one with thyrotoxicosis and the case of arachnoid cyst. $\dagger$ Includes the case of neurofilbroma and two cases invalided on psychiatric grounds, 
Table V

Present disposal of subjects with radiological lumbosacral abnormalities

\begin{tabular}{l|c|c|c|c|c}
\hline Subjects & Fully fit & $\begin{array}{c}\text { Downgraded and } \\
\text { restricted duties }\end{array}$ & Invalided & $\begin{array}{c}\text { Not } \\
\text { Traced }\end{array}$ & Totals \\
\hline Serving & 12 & 3 & -39 & 5 & 15 \\
\hline Not serving & 5 & 16 & 39 & 5 & 80 \\
\hline \multicolumn{1}{c}{ Totals } & 17 & 19 & 55 \\
\hline
\end{tabular}

\section{Discussion}

The distribution of conditions into the groups as described, shows an incidence of 12.5 per cent fractures, 32 per cent lumbar disc lesions, and 55.5 per cent non-specific backache. A previous survey carried out by Sheffield (1962) among 889 military personnel, found 23.6 per cent with a diagnosis of lumbar disc lesion, and 52.2 per cent with a diagnosis of lumbar or lumbosacral strain. Sheffield however revealed only 2 per cent with lumbosacral abnormalities compared with 18 per cent in the present survey. Both the difference in proportion of lumbar disc lesion and lumbosacral abnormalities between the two surveys are statistically significant. This difference could be related to different diagnostic criteria, as previously indicated.

The present results shows that at the time of the survey, only 35.5 per cent were considered to be fully fit. There were 60.5 per cent left with some degree of disability, including 35.5 per cent who had been invalided from the Services, excluding the ten cases for other reasons, all as a direct result of their back condition. This undoubtedly reveals a considerable wastage of manpower, quite apart from the personal morbidity.

The prognosis of those with lumbar disc lesions and radiological lumbosacral abnormalities was particularly poor, only 19.5 per cent and 21 per cent respectively returning to full fitness.

A survey carried out by Zinovieff (1966) who followed-up 100 coalminers with spinal injury over six months, at the Durham Miners Rehabilitation Centre, showed a somewhat similar pattern. Both groups of patients could generally be considered to lead an active and strenuous existence, although the average age of his cases was 38.8, considerably higher than in this survey. The comparative proportions are shown in Table VI, and his group of strains would reasonably be expected to correspond to the non-specific group in this survey.

Table VI

Distribution of condition groups

\begin{tabular}{l|c|c|c}
\hline \multicolumn{1}{c|}{ Survey } & $\begin{array}{c}\text { Fractures } \\
\text { (per cent) }\end{array}$ & $\begin{array}{c}\text { Lumbar disc lesions } \\
\text { (per cent) }\end{array}$ & $\begin{array}{c}\text { Strains or } \\
\text { non-specific group } \\
\text { (per cent) }\end{array}$ \\
\hline Zinovieff survey & 33 & 25 & 42 \\
Present survey & 12.5 & 32 & 55.5 \\
\hline
\end{tabular}


The higher proportion of fractures in Zinovieff"s survey was probably accounted for by the nature of the work and injuries in his cases. The comparison of the disposal of the two surveys is shown in Table VII, and shows no significant difference in the proportion regaining full fitness in all three groups.

Table VII

Final disposal of two surveys

\begin{tabular}{l|c|c|c|c}
\hline \multicolumn{1}{c|}{ Survey } & $\begin{array}{c}\text { Fractures } \\
\text { (per cent) }\end{array}$ & $\begin{array}{c}\text { Lumbar disc lesions } \\
\text { (per cent) }\end{array}$ & $\begin{array}{c}\text { Strains or } \\
\text { non-specific group } \\
\text { (per cent) }\end{array}$ & $\begin{array}{c}\text { Totals } \\
\text { (per cent) }\end{array}$ \\
\hline $\begin{array}{l}\text { Zinovieff survey } \\
\text { Fit for normal work }\end{array}$ & 25 & 20 & 33.5 & 27 \\
$\begin{array}{l}\text { Fit for light work } \\
\text { Unfit for mining }\end{array}$ & 69 & 64 & 50 & 60 \\
\hline Present survey & 6 & 16 & 16.5 & 13 \\
Fit for normal work & 39.5 & 19.5 & 43.5 & 35.5 \\
Downgraded or invalided & 57 & 75 & 53 & 60.5 \\
\hline
\end{tabular}

It was not considered possible to separate the downgraded and invalided group in the present survey so as to correspond strictly with Zinovieff's cases, since many of those invalided would be capable of light work.

Overall, the figures from the present survey, while indicating that fitness for full duty is obtained by one in three cases with fractured lumbar vertebrae, compared with one in five with a lumbar disc lesion and three in seven with non-specific backache, do not however show any statistically significant difference in the proportions of fully fit, downgraded and invalided disposals, in the three condition groups.

\section{Acknowledgements}

I am indebted to A.M.D. Stats for advice, to Officer's-in-Charge of Military Records Offices for their co-operation, and to Sergeant M. J. Burdett, R.A.M.C., Physiotherapist for assistance in accumulating data.

\section{REFERENCES}

Armstrong, J. R. (1965). Lumbar Disc Lesions, 3rd ed. E. \& S. Livingstone. Edinburgh. SHEFFIELD, F. J. (1962). Milit Med. 127, 232.

ZINOVIEFF, A. (1966). Proc. roy. Soc. Med. 59, 845. 